\title{
Ultra-high-pressure metamorphic rocks in China
}

Ultra-high-pressure rocks are found in huge slabs associated with low-pressure gneisses. They were formed by collision between the Yangtze and Sino-Korean blocks in the Late Permian to Early Triassic. Materials from an island arc on the south edge of the Sino-Korean block and from the passive margin of the Yangtze block were subducted to mantle depths and metamorphosed under high pressurellow temperature conditions. They were then exhumed by a 'corner flow' mechanism. Thickening of the continental crust in the deep portion of the collision zone could slow subduction. Afterwards, ascending asthenosphere could cause an increase in the geothermal gradient and further exhumation of UHP rocks by lithospheric extension.

\section{Introduction}

Ultra-high-pressure (UHP) metamorphic rocks were found ten years ago in the Western Alps (Chopin, 1984) and the Norwegian Caledonides (Smith, 1984) and more than five years ago in China (Xu, 1987; Okay et al., 1989; Wang et al., 1989). Since then, Chinese geologists have made great progress in the study of UHP rocks in cooperation with foreign geologists. New development in the field and ideas on the formation and exhumation of UHP metamorphic rocks are presented in this paper.

Table 1 Various UHP rocks and their typical assemblages in the Dabie-Su(Jiangsu)-Lu(Shandong) region.

\begin{tabular}{|c|c|c|c|}
\hline Lithology & Occurrence & $\begin{array}{l}\text { UHP metamorphic } \\
\text { mineral assemblages* }\end{array}$ & $\begin{array}{l}\text { Peak } \\
\text { metamorphic } \\
\text { P-T ranges }\end{array}$ \\
\hline Eclogite & $\begin{array}{l}\text { Blocks or layers in } \\
\text { gneiss, marble, or } \\
\text { ultramafic rocks }\end{array}$ & $\begin{array}{l}\text { Coe }+ \text { Diam }+ \text { Grt }+ \text { Omp } \\
+ \text { Rut } \pm \text { Kya } \pm \text { Phn } \pm \text { Epi }\end{array}$ & $\begin{array}{l}28-40 \mathrm{kbar} \\
700-900^{\circ} \mathrm{C}\end{array}$ \\
\hline $\begin{array}{l}\text { Mafic to } \\
\text { ultramafic } \\
\text { rocks }\end{array}$ & Blocks in gneiss & $\begin{array}{l}\text { Grt+Cpx+low } \mathrm{Al} \\
\mathrm{Opx}+\mathrm{Ol} ; \\
\mathrm{En}+\mathrm{Chl} \pm \mathrm{Ti} \\
\mathrm{Clinohumite} \pm \mathrm{Di} \pm \mathrm{Mgs} \\
\pm \mathrm{Ol} \pm \mathrm{Rt}\end{array}$ & $\begin{array}{l}35->50 \mathrm{kbar} \\
700-900^{\circ} \mathrm{C}\end{array}$ \\
\hline $\begin{array}{l}\text { Jadeitic } \\
\text { quartzite }\end{array}$ & $\begin{array}{l}\text { Interlayered with } \\
\text { marble and eclogite }\end{array}$ & Coe/Qtz+Jadeite & $\begin{array}{l}>28 \mathrm{kbar} \\
600-750^{\circ} \mathrm{C}\end{array}$ \\
\hline $\begin{array}{l}\text { Schist and } \\
\text { gneiss }\end{array}$ & $\begin{array}{l}\text { Interlayered with } \\
\text { eclogite }\end{array}$ & $\begin{array}{l}\text { Coe/Qtz+Grt+Zoi+ } \\
\text { Kya+Phn; } \\
\text { Grt+Rut+Al Ttn }\end{array}$ & $\begin{array}{l}>28 \mathrm{kbar} \\
-600^{\circ} \mathrm{C}\end{array}$ \\
\hline Marble & $\begin{array}{l}\text { Layers or lenticular } \\
\text { blocks }\end{array}$ & $\begin{array}{l}\mathrm{Coe}+\mathrm{Grt}+\mathrm{Di} / \mathrm{Omp}+ \\
\text { Phn+Cal/Arg+Dol+Ep } \\
+ \text { +Rut }\end{array}$ & $\begin{array}{l}>28 \mathrm{kbar} \\
630-760^{\circ} \mathrm{C}\end{array}$ \\
\hline
\end{tabular}

* Mineral abbreviations after Kretz (1983)

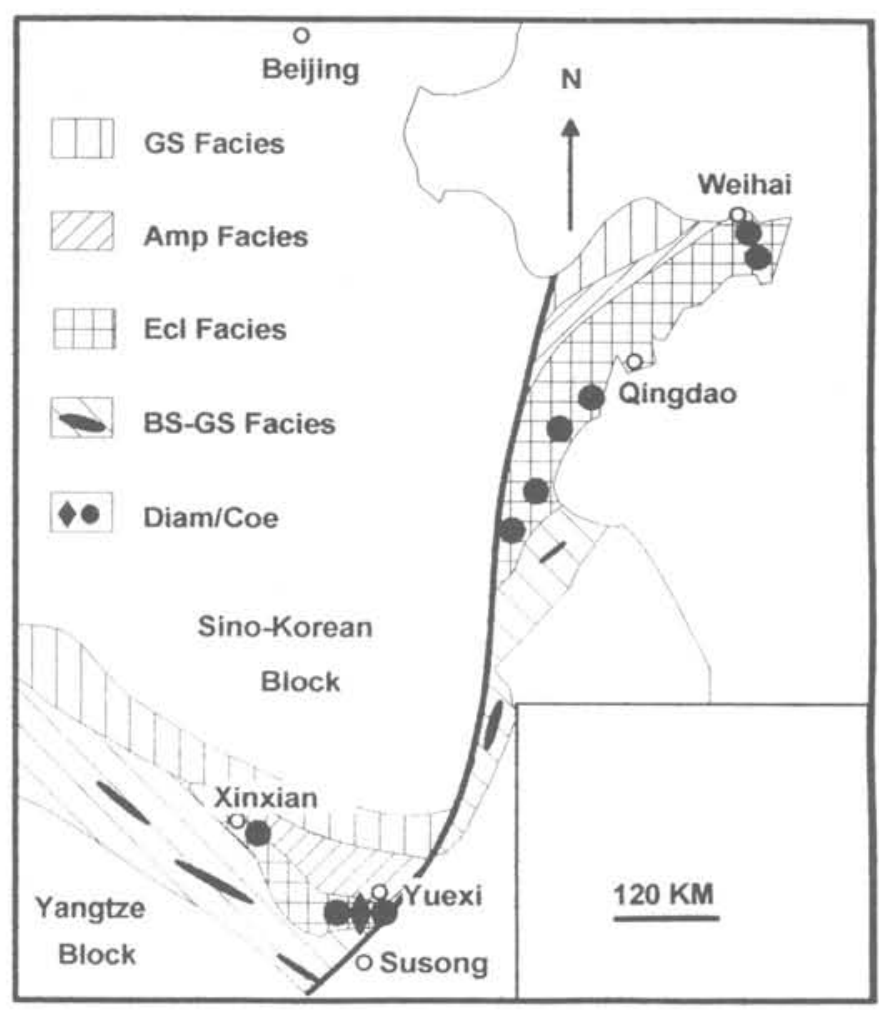

Figure 1 UHP rocks in China.

\section{The occurrence of UHP rocks in China}

All of the UHP rocks so far found in China occur in the DabieJiangsu-Shandong region, in the Mesozoic collisional orogen between the Yangtze and the Sino-Korean blocks (Figure 1). Apart from coesite- and diamond-bearing eclogite (Okay et al., 1989; Wang et al., 1989; Xu et al., 1992), various UHP rocks have been reported, such as meta-ultramafics (Ye and Xu, 1992; Fan et al., 1992; Zhang et al., 1994; Okay, 1994), jadeitic quartzite (Zhai et al., 1992), schist and gneiss (Wang and Liou, 1991; Cong et al., 1995), and marble (Wang and Liou, 1991, 1993; Ye, 1993). Their diagnostic assemblages are summarized in Table 1.

Though various rocks have undergone UHP metamorphism, it could not be proven that the Dabie-Jiangsu-Shandong region is a coherent UHP terrane. Detailed mapping of a small area (Figure 2) in the hinterland of the Dabie Mountains showed that the UHP rocks usually comprise huge slabs associated with low-pressure gneiss (Cong et al., 1995). The region in which the UHP rocks occur is bounded also by a ductile shear zone (Wang et al., 1994).

\section{Tectonic background of UHP metamorphism}

The UHP rocks from the Western Alps were considered to be the result of subduction of crustal sediments to the depth of about 100 km (Chopin, 1984; 1987). In the case of the Dabie-Jiangsu-Shan- 


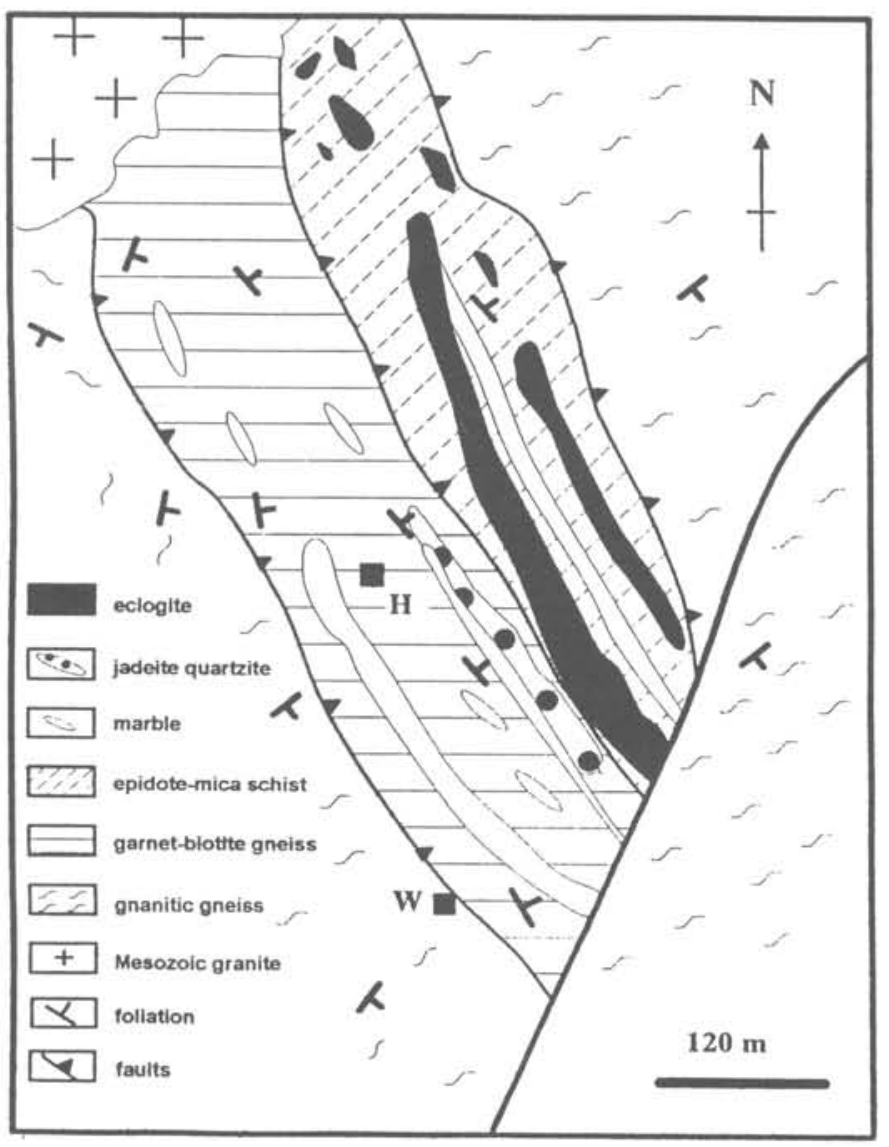

Figure 2 UHP slabs in the Shuanghe region, Dabie Mountains $H$ Hanchangchong; W Wangdawu.

dong region, the UHP rocks are of various types, with the protoliths obviously from different environments.

Eclogites from the Dabie-Jiangsu-Shandong region may be divided into three types according to their host rocks. The first type occurs as blocks or lenticular bodies in gneisses; the second is surrounded by marble; and the third is enclosed by ultramafic rocks. Their REE patterns show that the eclogites were metamorphosed from various rocks (Figure 3 ). The first type are enriched in LREE to different extents. Some show an obvious LREE-enriched pattern similar to the IAB, while others have a less-enriched pattern similar to E-type MORB (Figure 3A). The eclogites occurring in ultramafic rocks also vary in their REE contents (Figure 3B). Some are LREE enriched, while others are MREE enriched indicating a cumulate affinity.

Petrological data show that the UHP gneisses fall in the sediment field with wider $\mathrm{SiO}_{2}$ ranges and higher $\mathrm{TiO}_{2}$ contents. They have lower abundances of LIL and HFS elements. In the ACF diagram (Winkler, 1976), they overlap the field of graywacke, clay and marl.

Furthermore, the $\mathrm{Rb}-\mathrm{Sr}$ and $\mathrm{Sm}-\mathrm{Nd}$ isotopic data ( $\mathrm{Li}$ et al., 1993) show that some eclogites with island arc features have low $\mathrm{Sm} / \mathrm{Nd}$ ratios, low $\mathrm{Rb} / \mathrm{Sr}$ ratios, and low $\epsilon_{\mathrm{Nd}}$ values, as well as older $\mathrm{Nd}$ isotope model ages $\left(\mathrm{T}_{\text {CHUR }}>1736 \mathrm{Ma}\right)$. This might imply that the island arc basalts were mixed with, and contaminated by, Precambrian continental materials when they were metamorphosed together under UHP conditions. Such a mixture could be a tectonic melange generated during subduction.

The meta-ultramafic rocks also have different protoliths. Some came directly from deep-seated hot mantle, with a pre-UHP history of decreasing pressure and temperature (Yang et al., 1993). Others have a pre-UHP history of increasing pressure, implying that they came from cold crystallized cumulate (Okay, 1994; Zhang et al.,
A) Eclogites in gneiss

O Dabie

$\Delta$ Su-Lu

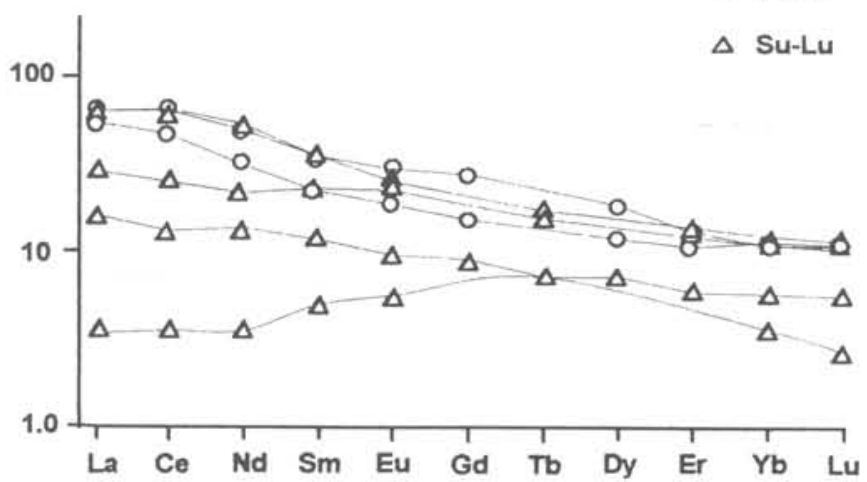

B) Ultramafics and enclosed eclogites

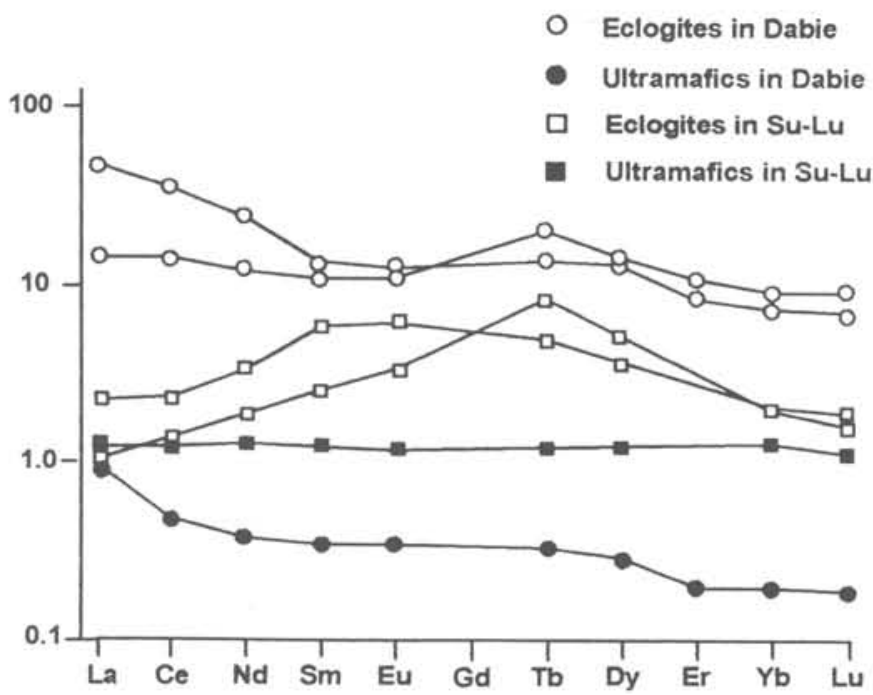

Figure 3 REE patterns for eclogite from gneiss (3-A) and for ultramafic rocks and their associated eclogite (3-B).

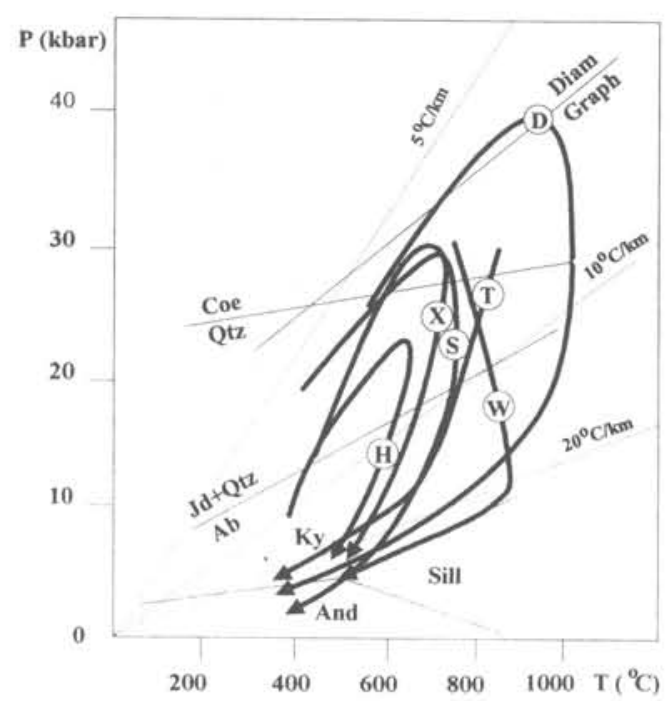

Figure $4 \mathrm{P}-\mathrm{T}$ paths of eclogite from the Dabie-Su (Jiangsu)-Lu (Shangdong). 


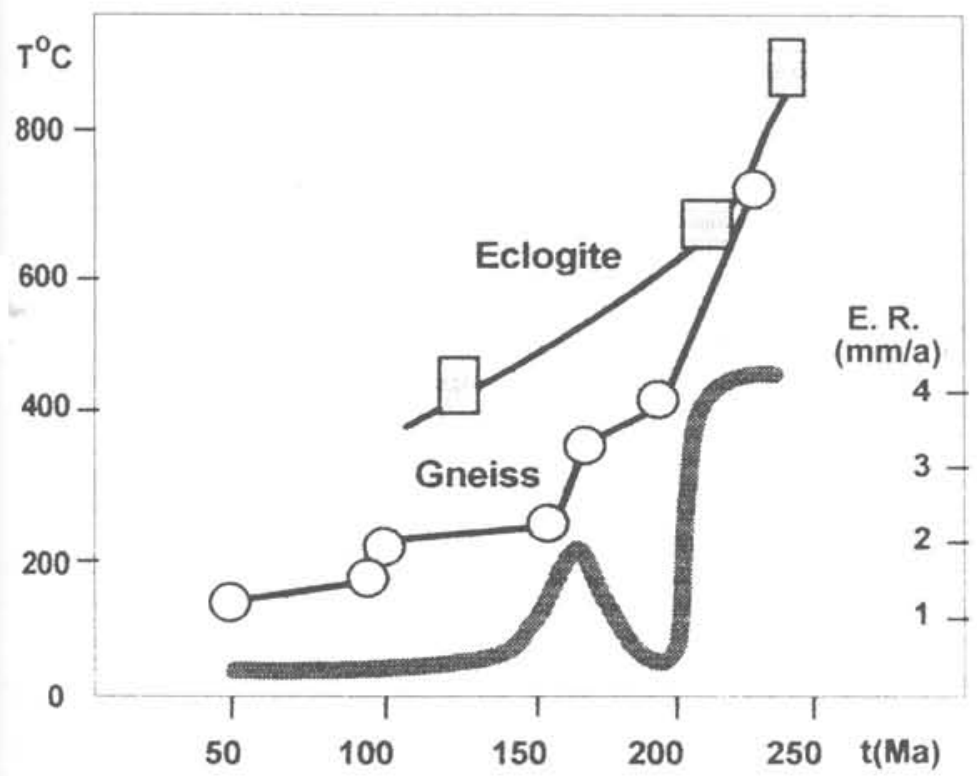

Figure 5 T-t paths of eclogite and gneiss from the Dabie Mountains. E. $R$. exhumation rate.

1994). This indicates that part of the lithospheric mantle was involved in the tectonism that caused the UHP metamorphism.

Available geochronologic data from $\mathrm{U}-\mathrm{Pb}, \mathrm{Sm}-\mathrm{Nd}$ and $\mathrm{Rb}-\mathrm{Sr}$ determinations indicate that the age of peak UHP metamorphism ranges from the Late Permian to the Early Triassic ( $\mathrm{Li}$ et al., 1989, 1992, 1993; Cong et al., 1992; Ames et al., 1993) coincident with the beginning of collision between the Yangtze and Sino-Korean blocks (Hsu et al., 1987; Li et al., 1989; 1993). Therefore, the authors infer that during the initial collision island arc materials from the southern margin of the Sino-Korean block and from the passive margin of the Yangtze block were subducted deep into the mantle and underwent UHP metamorphism there.

\section{Exhumation of UHP rocks}

The exposure of the UHP rocks in the collisional orogenic belt implies that the exhumation of the UHP rocks might be an integrated process in the collisional orogeny. Many P-T paths have been summarized from different localities in the Dabie-Jiangsu-Shandong region (Wang et al., 1992; Xu et al., 1992; Li et al., 1993; Wang et al., 1993; Zhang and Liou, 1994; Zhang et al., 1994). A common trend of these paths is that the geothermal gradient gradually increased when the UHP rocks were transported upwards (Figure 5). During the initial stage of exhumation the geothermal gradient was lower than $10^{\circ} \mathrm{C} / \mathrm{km}$, which implied that a cold lithosphere plate continued its subduction. During the later stage of exhumation the geothermal gradient went up to about $20^{\circ} \mathrm{C} / \mathrm{km}$ or even higher. It might imply that the cold plate has stopped subduction. The T-t path (Figure 5) shows that the UHP rocks moved from a depth of $110 \mathrm{~km}$ to $35-40 \mathrm{~km}$ by $221 \mathrm{Ma}$ ( $\mathrm{Li}$ et al., 1993). The peak metamorphic age of coesite-bearing eclogites from the Dabie Mountains has been dated at $236 \mathrm{Ma}(\mathrm{Li}$ Shuguang, 1994, personal communication). Therefore, the average exhumation rate was about $4 \mathrm{~mm} /$ year between $236 \mathrm{Ma}$ and $221 \mathrm{Ma}$, and about $0.2 \mathrm{~mm} /$ year between $221 \mathrm{Ma}$ and $124 \mathrm{Ma}$ (Figure 5). A recent thermal geochronological study of the multiple diffusion domain ${ }^{40} \mathrm{Ar}-{ }^{39} \mathrm{Ar}$ in gneiss (Chen and Wang, in press) indicates that the average exhumation rate was larger than $3 \mathrm{~mm} /$ year before $210 \mathrm{Ma}, 1.5 \mathrm{~mm} /$ year around $160 \mathrm{Ma}$, and less than $0.5 \mathrm{~mm} /$ year after $140 \mathrm{Ma}$ (Figure 5). In addition, the earliest terrestrial sediments in the Dabie Mountains were the middle Early Jurassic pebbly sandstone (Anhui Bureau of Geology and Mineral Resources, 1987), with an age about $200 \mathrm{Ma}$.

From these data, three exhumation stages can be discerned.

- In the first stage, between 240 and $220 \mathrm{Ma}$, the Dabie Mountains had not taken shape in a geomorphological sense. The UHP rocks, however, had begun to be very rapidly exhumed at an average exhumation rate of $4 \mathrm{~mm} /$ year. The low geothermal gradient $\left(10^{\circ} \mathrm{C} / \mathrm{km}\right)$ in this stage implied that the subduction of the Yangtze continental block might still be going on. The contemporaneous exhumation of the UHP rocks with the subduction of the Yangtze continental block might imply that 'corner flow' (Cowan and Silling, 1978) was the main exhumation mechanism.

- The second stage was between 220 and $150 \mathrm{Ma}$, when the Dabie Mountains appeared. The increase of the geothermal gradient to $20^{\circ} \mathrm{C} / \mathrm{km}$ might imply that subduction of the Yangtze continental block had stopped. A release of the tectonic compression energy after accumulation might be implied by the change of the exhumation rate from almost zero to $1.5 \mathrm{~mm} /$ year. Retrograded metamorphism of amphibolite facies started at this stage.

- The third stage started in $150 \mathrm{Ma}$. The low exhumation rate $(<0.5 \mathrm{~mm} /$ year) implied regional uplift and erosion. There was extensive intrusion of granite during this stage (Zhang and Sun, 1990).

\section{Conclusions}

1 It has been argued for a long time whether or not the Norwegian eclogite and its country gneiss were metamorphosed together under a high-pressure environment (Smith, 1988). In the DabieJiangsu-Shandong region, we have had a similar debate on the question of whether the eclogites belong to a tectonic melange (Liu et al., 1989; Xu et al., 1992) or to a coherent UHP terrane (Wang and Liou, 1991; Okay, 1993; Okay et al., 1993). Our detailed mapping shows that the country rocks of the eclogite can be divided into two kinds. One has experienced UHP metamorphism together with the host eclogites, but the other has never experienced UHP metamorphism. The former occur together with the host eclogite in huge slabs which are in tectonic contact with the latter.

2 Isotopic dating indicates that UHP metamorphism took place during initial collision between the Yangtze and the SinoKorean continental blocks. The REE data show a diversity of the protoliths. The UHP rocks are metamorphosed materials from the Yangtze passive margin, an island arc, as well as oceanic crust.

3 Based on the P-T-t paths of the UHP rocks in the DabieJiangsu-Shandong region, the exhumation process of the UHP rocks can be divided into three stages. During the first and main stage, the UHP rocks were exhumed from $110 \mathrm{~km}$ to about $40 \mathrm{~km}$. They were exhumed to middle crust levels in the second stage, then uplifted and eventually exposed together with the middlecrust rocks at the surface during the third stage.

4 The increase in geothermal gradient during the second exhumation stage implies that the continental crust could not continue its subduction down to the deep mantle because the low density would prohibit subduction. The mountain building process of the Dabie orogenic belt coincided with the second and third exhumation stages. 


\section{References}

Ames, L, Tilton, G R, and Zhou, G, 1993, Timing of collision of the SinoKorean and Yangtze Cratons, China: Geology, v. 21, pp.339-342.

Anhui Bureau of Geology and Mineral Resources, 1987, Regional geology of Anhui Province: Geological Publishing House, Beijing, 726pp. (in Chinese).

Chopin, C, 1984, Coesite and pure pyrope in high-grade blueschists of the Western Alps: a first record and some consequences: Contributions to Mineralogy and Petrology, v. 86, pp.107-118.

Chopin, C. 1987, Very-high-pressure metamorphism in the western Alps: implications for subduction of continental crust, in Oxburgh, E R, Yardley, B W D, England, P C, eds., Tectonic settings of Regional Metamorphism. Philosophical Transactions of the Royal Society, London, ser. A, no. 321, pp.183-197.

Cong, B, Zhang, R, Li, S, Zhai, M, Wang, S, Chen, C, and Ishiwatari, A, 1992, Preliminary study of isotope chronology of eclogites in northern Jiangsu and eastern Shandong Provinces, China, in Commemorative Association for Prof. Y, Matsumoto, Exploration of Volcanoes and Rocks in Japan, China and Antarctica, pp.411-418.

Cong, B, Zhai, M, Carswell, D A, Wilson, R N, Wang, Q, Zhao, Z, and Windley, B F, 1995, Petrogenesis of ultrahigh-pressure rocks and their country rocks at Shuanghe in Dabieshan, Central China, European Journal of Mineralogy, v. 7, pp.119-138.

Cowan, D S, and Silling, R M, 1978, A dynamic scaled model of accretion at trenches and its implications for the tectonic evolution of subduction complexes: Journal of Geophysical Research, v, 83, pp.5389-5396.

Fan, Q, Liu, R and Ma, B, 1992, A preliminary study of high-pressure metamorphism of ultramafic rocks in north Jiangsu-south Shangdong region: Acta Petrologica Sinica, v. 8, pp.90-96 (in Chinese).

Li, S, Hart, S R, Zheng, S, Liou, D, Zhang, G, and Guo, A, 1989, Timing of collision between the North and South China Blocks - Sm-Nd isotopic age evidence: Science China (Ser. B), v. 32, pp.1391-1400.

Li, S, Liu, D, Chen, Y, and Ge, N, 1992, The Sm-Nd isotopic age of coesitebearing eclogite from the southern Dabie Mountains: Chinese Science Bulletin, v. 37, pp.1638-1641.

Li, S, Xiao, Y, Liou, D, Chen, Y, Ge, N, Zhang, Z, Sun, S, Cong, B, Zhang, R, Hart, S R, and Wang, S. 1993, Collision of the North China and Yangtze blocks and formation of coesite-bearing eclogites: timing and processes: Chemical Geology, v. 109, pp.89-111.

Liu, R, Ma, B, Zhang, Z, Zhang, Zh, Yang, H, and Hu, L, 1989, Geology and lithological column of the north Jiangsu-south Shangdong melange zone: Seismic Geology, v. 11, pp.47-54 (in Chinese).

Okay, A I, 1993, Petrology of a diamond and coesite-bearing terrain: Dabie Shan, China: European Journal of Mineralogy, v. 5, pp.659-675.

Okay, A I, Sengor, A M C, and Satir, M, 1993, Tectonics of an ultra-highpressure metamorphic terrane: the Dabie Shan/Tongbai Shan orogen, China: Tectonics, v. 12, pp.1320-1334.

Okay, A 1, 1994, Sapphirine and Ti-clinohumite in ultra-high-pressure garnet- pyroxenite and eclogite from Dabie Shan, China: Contributions to Mineralogy and Petrology, v. 116, pp.145-155.

Schreyer, W, Massonne, H J, and Chopin, C, 1987, Continental crust subducted to depths near $100 \mathrm{~km}$ : implications for magma and fluid genesis in collision zones. Magmatic processes: physiochemical principles: Geochemical Society, Special Publication, 1, pp.1-155.

Smith, D C, 1984, Coesite in clinopyroxene in the Caledonides and its implications for geodynamics: Nature, v. 3, pp.641-644.

Smith, D C, (ed.), 1988, Eclogites and Eclogite-facies Rocks: Elsevier, Amsterdam. 524pp.

Wang, Q, Ishiwatari, A, Zhao, Z, Hirajima, T, Hiramatsu, N, Enami, M, Zhai, M, Li, J and Cong, B, 1993, Coesite-bearing granulite retrograded from eclogite in Weihai, Eastern China: European Journal of Mineralogy, v. 5, pp.141-153.

Wang, Q, Liu, X, Maruyama, S, and Cong, B, 1994, Top boundary of the Dabie UHPM rocks, central China: Journal of Southeast Asian Earth Sciences (in press).

Wang, S, Liou, J G, and Maruyama, S, 1992, Coesite-bearing eclogites from the Dabie Mountains, Central China: petrogenesis, P-T paths and implications for regional tectonics: Journal of Geology, v. 100, pp.231-250.
Wang, X, and Liou, J G, 1991, Regional ultrahigh-pressure coesite-bearing eclogite terrane in eastern China: evidence from country rocks, gneiss, marble, and metapelite: Geology, v. 19, pp.933-936.

Wang, X, and Liou, J. G, 1993, Ultra-high-pressure metamorphism of carbonate rocks in the Dabie Mountains, central China: Journal of Metamorphic Geology, v. 11, pp.575-588.

Xu, S, Jiang, L, Zhang, Y, and Zhang. Y, 1992, Tectonics and evolution of the Dabie Mountains (Anhui segment): Acta Geologica Sinica, v. 66, pp.1-14 (in Chinese).

Xu, S, Okay, A I, Ji S, Sengor, A M C, Su, W, Liu, Y, and Jiang, L, 1992, Diamond from the Dabie Shan metamorphic rocks and its implication for tectonic setting: Science, v. 256 , pp. $80-82$.

$\mathrm{Xu}, \mathrm{Z}, 1987$. Etude tectonique et microtectonique de la chaine Paleozoic et Triasique des Quilings (Chine): Doctorate Thesis, University of Science and Technology, Languedoc, Montpellier.

Yang, J, Godard, G, Kienast, J, Lu, Y, and Sun, J, 1993, Magnesite-bearing garnet peridotites from northeastern Jiangsu, China: Journal of Geology, v. 101, pp.541-554.

$\mathrm{Ye}, \mathrm{K}$, and $\mathrm{Xu}, \mathrm{P}, 1992$, Petrogenesis of eclogites and related peridotitic rocks in Datong area of Rongcheng County, Shandong Province: Acta Petrologica Sinica, v. 8, pp. 27-39 (in Chinese).

$\mathrm{Ye}, \mathrm{K}, 1993$, Metamorphism of eclogites and related rocks and their tectonic significance in the northeastern Shangdong Province: Doctoral thesis. Institute of Geology, Academia Sinica, 94pp (in Chinese).

Zhai, M, Cong B, Zhao, A, Wang, Q, and Li, J, 1992, High pressure jadeiite in the Dabie eclogite zone and its implication: Chinese Science Bulletin, v. 37, pp.1013-1015 (in Chinese).

Zhang, D and Sun, G, 1990, Emplacement age of the Tiantangzhai granite and its geological significance in the Dabie Mountains: Journal of Petrology and Mineralogy, v. 9, pp. 31-36. (in Chinese)

Zhang, R, and Liou, J G, 1994, Coesite-bearing eclogite in Henan Province, central China: detailed petrography, glaucophane stability and PT-path: European Journal of Mineralogy, v. 6, pp.217-233.

Zhang, R, Liou, J G, and Cong, B, 1994, Petrogenesis of garnet-bearing ultramafic rocks and associated eclogites in the Su-Lu ultrahigh-P metamorphic terrane, eastern China: Journal of Metamorphic Geology, v. 12, pp.169-186.

Bolin Cong was born in 1939 and graduated from Beijing University in 1963. He has worked on petrogenesis and tectonics, and has published more than 80 papers in Chinese and international journals, as well as five monographs. He is now the leader of a key project, financially supported by the National Natural Science Foundation of China, to study UHP metamorphic rocks in the DabieJiangsu-Shandong region.

Qingchen Wang was born in 1950 and obtained his PhD in 1985 from the Graduate School of the Chinese Academy of Sciences. His major interests are in petrology and tectonics, and he has published more than 40 papers in Chinese and international journals. Since 1989, he has been studying UHP metamorphic rocks in the DabieJiangsu-Shandong region.
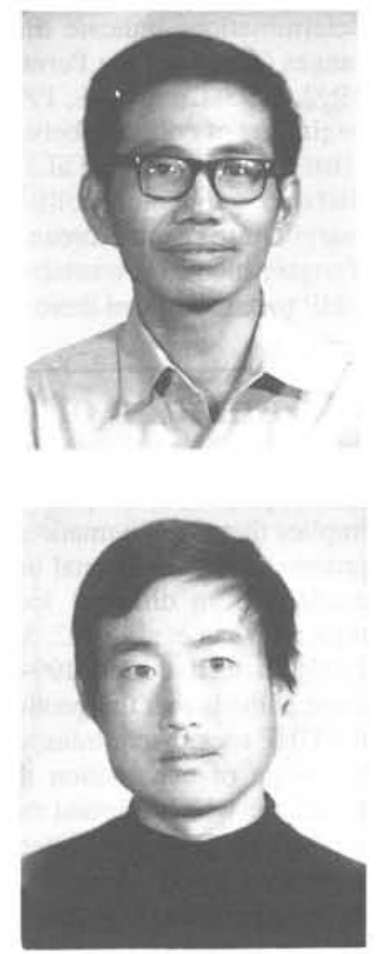